\title{
A gyógytestnevelés feladata, jelenlegi helyzete az oktatás rendszerében
} Task of Adapted PE and its Present Position in Education

\author{
Andrásné Teleki Judit \\ Testnevelési Egyetem, Egészségtudományi és Sportorvosi Tanszék, Budapest
}

\begin{abstract}
Absztrakt: A mozgás a fogantatásunktól kezdve végigkíséri életünket. Létfontosságú, mert általa fejlódik személyiségünk, fizikumunk, testünk-lelkünk. A gyermekek többször átesnek fejlődésük olyan szakaszán, amikor nincs összhangban növekedésük az izomerejük fejlődésével. Ezen időszakban külső látható jelei vannak a fejlődési diszharmóniának, melynek kezdődő megnyilvánulási formája, a hanyag tartás, amely idővel - speciális mozgás hiányában - komoly gerinc-deformitásokhoz vezet(het). Ahhoz, hogy ezek az elváltozások ne jelentsenek egész életre szóló hátrányt, szükség van a gyógytestnevelésre. Amennyiben az elváltozások nem olyan mértékúek, hogy akadályoznák az iskolába járást, addig a gyógytestnevelés feladata az egészségi állapot helyreállítása, javítása, szinten tartása és rehabilitációja. A gyógytestnevelési foglalkozásokon végzett speciális gyakorlatanyaggal az elváltozások javíthatók, sok esetben helyre is állíthatók. Sajnálatos, hogy ez a speciális feladatellátás a 2013. évi jogi szabályozás hatálybalépését követően kikerült a nevelési-oktatási intézmények hatásköréból, ezzel együtt elvesztette az iskolák általi elfogadottságot, támogatottságot, amivel a „hungarikum” megtiszteló minősítést megszerezte.
\end{abstract}

Kulcsszavak: gyógytestnevelés, feladatellátás, jogi szabályozás, jelen helyzet

Abstract: Motion accompanies our life from birth. It is of crucial importance as our personality, physique, body and soul develop through it. Children often have to face such situations when their growth is not in accordance with the development of their muscle strength In these periods, there are obvious signs of developmental disharmony, for example loose body stance which can lead to severe spine deformities if no special exercise is taken. Adapted Physical Education is needed to avoid a life-long handicap due to these deformities. If the rate of distortion is not as serious to prevent the child form going to school, Adapted PE is meant to restore, maintain or rehabilitate health. Special exercises can correct or even eliminate deformities. Unfortunately, this special care has been dismissed from the majority of educational institutions due to the enforcement of legal regulation from 2013, thus losing the acceptance and support of schools which had granted it the honourable 'Hungaricum' title.

Keywords: Adapted PE, care, legal regulation, present situation

\section{Bevezetés}

A tanulók többször átesnek fejlödésük olyan szakaszán, amikor növekedésük nincs összhangban az izomerejük fejlődésével. Ezen időszakban külső látható jelei vannak a fejlődési diszharmóniának, melynek kezdődő megnyilvánulási formája, a hanyag testtartás, amely idővel - speciális mozgás hiányában - komoly mozgásszervi elváltozáshoz vezet(het). Mindemellett még a növekvő fizikai és szellemi követelményrendszerek elvárásait is próbálják teljesíteni, e közben aránytalanság alakulhat ki a gyermek terhelése és terhelhetősége, az igénybevétel és az aktuális képességek között. A mozgásszegény életmód, a fizikai tevékenységek csökkenése, a levegőszennyeződés, a zsúfoltság, a zajártalom a végsőkig fokozzák a tanulókra gyakorolt nem kívánatos hatásokat, ezért ma már egyre több az 
iskoláskorúak körében a vegetatív-labilis fiatal.

A testi nevelésnek a korrekció és a fejlesztés mellett van egy további részfeladata is, nevezetesen a szervezet aktív megerősítése, amely az egészség gyengülésének, elvesztésének megelözését, a prevenciót biztosítja. A preventív tornával megelőzhetők az elváltozások, ezért ez a torna a testnevelés részét képező gyógytestnevelési kategóriák alapja.

\section{A gyógytestnevelés feladata}

A gyógytestnevelés, mint testnevelési alternatíva, rehabilitációs és gyógyító mozgásos tevékenységek testnevelése. A testnevelési kategóriákba sorolás iskolaorvosi feladat. Amennyiben az iskolaorvos a tanulónál mozgásszervi vagy belgyógyászati elváltozást diagnosztizál, a testnevelés részét képező gyógytestnevelési kategóriákba sorolja, melyek a következők:

- Könnyített testnevelés

- Gyógytestnevelés

- II/a Testnevelés órán is részt vehet

- II/b Csak gyógytestnevelésen vehet részt

- Felmentett (egészségügyi intézményben gyógytorna)

A gyógytestnevelésre beosztott tanulók egészségi állapota eltér a többi tanulóétól, a különbségek morfológiai és funkcionális vonatkozásúak. A szomatikus (testi) eltérés mellett gyakran pszichés eltérések is találhatók.

A gyógytestnevelés tevékenységi körét, feladatát többen is meghatározták, így Nemessurri (1965) „A gyógytestnevelés az a tudományág, amely a testnevelés módszereinek felhasználásával betegségek megelőzésére és gyógyítására alkalmas". Gárdos és Mónus (1991) a gyógytestnevelést az alábbiak szerint határozták meg: „A gyógytestnevelés, mint a testnevelés- és sporttudományok egyik ága, rendszerbe foglalja azokat az ismereteket, amelyek az egészségi állapotnak a testnevelés és sport eszközeivel, módszereivel való helyreállítását szolgálják". Mindezekből jól érzékelhető a gyógytestnevelés feladata: a betegségek megállítása és megszüntetése az egészségi állapot helyreállitása a testnevelés és sport speciális mozgásanyagának felhasználásával (a testi képességek és a mozgás fejlesztése, valamint a sportolási igény felkeltése).

A gyógytestnevelés fó célja: elérni, hogy a gyógytestnevelésre szorulók felzárkózhassanak egészséges társaikhoz.

Mindez a testnevelés mozgásanyagának speciális felhasználásával, a gyógytestnevelés módszereinek alkalmazásával érhető el.

A gyógytestnevelés közvetlen célfeladata, részfeladatokra bontott megvalósítása, az alábbiak szerint történik:

- Közvetlen terápiás jellegü feladatok

- Közvetett terápiás hatások (általános kondíció, teljesítőképesség növelése)

- Nevelési jellegü feladatok megoldása (a személyiség kedvező irányban történő befolyásolása)

- A gyógytestnevelés csoportosítása az elváltozások típusa szerint:

- A tartó- és mozgatórendszer elváltozásai

- Belgyógyászati és egyéb betegségek

- (A mozgásszervi betegséggel küzdők vannak nagyobb arányban.)

A gyógytestnevelés feladata nem csak az oktatás, a nevelés, hanem erőteljes szemléletformálás is. Az egészség helyreállítása akkor tekinthető befejezettnek, ha a prevenciós-korrekciós tevékenységek eredményeképpen a tanuló szervezete alkalmassá válik az iskolai testnevelésben megkívánt terhelés elviselésére. E kiemelten fontos feladatokat a gyógytestnevelő tanárok végzik, akik képzettségüknek megfelelően differenciáltan foglalkoznak a mozgásszervi elváltozásban szenvedő, a testi képességeikben visszamaradott tanulókkal. A gyógytestnevelő tanár egy olyan szakember, aki a testkultúra és az egészségügy interdiszciplináris területén fejt ki pedagógiai tevékenységet.

\section{A gyógytestnevelés helyzete az oktatás rendsze- rében}

Az elmúlt évek során egyre több szó esik az iskolai testnevelés részét képező gyógytestnevelési kategóriák feladatairól, lehetőségeiről és szerepéről.

Történik ez azért, mert a gyógytestnevelés iskolai rendszerében 2013-ban változás történt, az addigi iskolai gyógytestnevelési rendszert felülírta a 2013. március 1-én hatályba lépett 15/2013. (II. 26) EMMI rendelet, melynek 28. $\$(2)$ bekezdése értelmében „A gyógytestnevelés megszervezése, személyi feltételeinek biztosítása a pedagógiai szakszolgálat feladata.", mely szerint az iskolák gyógytestnevelési ellátása megszűnt. 2013-2017 januárjáig folyt a szakmai „harc” hogy maradjon a gyógytestnevelés a Pedagógiai Szakszolgálatoknál, vagy kerüljön viszsza a helyére, a nevelési-oktatási intézményekbe. A vita eldőlt: az oktatásirányítók végleges döntése alapján a gyógytestnevelési feladatellátás marad a 
Pedagógiai Szakszolgálatok rendszerében.

A döntést követően is maradtak további kérdések és anomáliák. Ilyen például, hogy a gyógytestnevelés a továbbiakban is a Pedagógiai Szakszolgálatok által kijelölt nevelési-oktatási intézményben szervezhető, feltétel a két intézmény közötti megállapodás megkötése. Joggal tehető fel az a kérdés, de mi lesz azokkal a nevelési-oktatási intézményekkel, melyekkel nem kötnek megállapodást? Ott ki fogja ellátni a gyógytestnevelésre utalt, rehabilitációra szoruló tanulókat? Nehezíti a feladatellátást az is, hogy az így is kevésnek bizonyuló gyógytestnevelő közül sokan - szakvizsga hiányában - igen nagy számban a Pedagógiai Szakszolgálatnál nem alkalmazhatók.

A jogi szabályozás alapján a gyógytestnevelők nem tagjai a nevelőtestületnek. A napi pedagógiai munka hiányában nem ismerik a tanulókat és nem tudnak megfelelő kapcsolatot kialakítani az intézmény vezetőjével, testnevelőjével és tanáraival. A gyógytestnevelés betegségmegelőző és gyógyító funkciót lát el, testnevelés órát vált ki, mint önálló tantárgy osztályozni kell úgy, hogy közben a NAT-ban nem szerepel. Jelenleg a nevelési-oktatási intézményeknek nincs felelőssége, de megfelelő kompetenciája sem a gyógytestnevelésre utalt tanulók speciális ellátását, szervezését illetően. Ennek tükrében azok a gyógytestnevelői végzettséggel rendelkező pedagógusok, akik nem tartoznak a Pedagógiai Szakszolgálatok intézményrendszerébe, a saját nevelési-oktatási intézményükben csak akkor tevékenykedhetnek gyógytestnevelőként, ha a Pedagógiai Szakszolgálat igényt tart a munkájukra, és a feladat ellátására megbízást ad. A gyógytestnevelésre utalt tanulóknak szükségük van egy olyan pedagógiai környezetre, ahol megértik őket, figyelnek rájuk, ahol a kevésbé jó fizikai teljesítményük is érték akkor, ha az elváltozásuk helyreállítása érdekében tudatosan és szorgalmasan együttmüködnek a gyógytestnevelő tanárukkal.

Hazánkban az Alapvető Jogok Biztosa jelentéséből tudható, hogy 2013-ban 6279 közoktatási intézményéből csak 2241 intézménnyel van megállapodása a Pedagógiai Szakszolgálatoknak a gyógytestnevelési feladatok ellátására. A gyógytestnevelési kategóriába soroltak száma 109153 fö, ebből 75419 tanuló gyógytestnevelésre, 24042 könnyített testnevelésre utalt. 9682 diák testnevelés alól felmentett: ők egészségügyi intézményekben gyógytornán vesznek részt. A 75419 tanuló gyógytestnevelési feladatát országosan 751 gyógytestnevelő tanár látja el, ebből 115 fó a fóvárosban, 645 fó pedig az ország 19 megyéjében tevékenykedik. Az óvodában végzett gyógytestnevelöi tevékenységről nincs adat, mivel az $\mathrm{OH}$ nem rendelkezik erre vonatkozó számokkal AJB (2013).

A KSH 2016. évi adatai alapján a gyógytestnevelési kategóriába soroltak összlétszáma 92796 fö, ebből gyógytestnevelésre 60771, könnyített testnevelésre 22924 tanuló utalt, az iskolai testnevelés alól felmentettek száma 8692. Az adatokból az tűnik ki, hogy a 2013-as adatokhoz képest 17000 fővel kevesebb tanuló került gyógytestnevelési kategóriába. Ez nem azt jelzi, hogy kevesebb tanuló szorulna a gyógytestnevelésre. A csökkenő számnak több oka is lehetséges, mégpedig:

- vagy nem fordítottak kellő figyelmet az egészségügyi szűrővizsgálatok során a testnevelési kategóriákba sorolásra,

- vagy a kiszűrt tanulók gyógytestnevelési ellátására nincs elegendő gyógytestnevelői végzettséggel rendelkező pedagógus.

A gyógytestnevelés feladatellátását nehezíti föleg a kisebb településeken - az is, hogy a szakvizsgával nem rendelkező gyógytestnevelők nem vehetnek részt a gyógytestnevelési feladatellátásban, ezért célszerű lenne a szakvizsga kötelezettség eltörlése, a gyógytestnevelés presztízsének növelése, a gyógytestnevelői munka elismerése, elismertetése.

\section{Összefoglalás}

A törvényi szabályozás következtében a gyógytestnevelés jelentős hátrányba került a közoktatás (köznevelés) intézményrendszerében azzal, hogy a gyógytestnevelést elválasztották a testneveléstől. Az új koncepció gyakorlatilag ellehetetleníti a testnevelés részét képező iskolai gyógytestnevelést. A hatályos jogi szabályozás a gyógytestnevelőket a Pedagógiai Szakszolgálatokhoz rendeli, de a feladatvégzés helyszíne változatlanul a nevelési-oktatási intézmény. A 11/1994. (VI. 8.) MKM rendelet 1. számú mellékletében foglaltak szerint változatlan maradt a gyógytestnevelési kategorizálás, de nem változott a heti órák száma és az uszodai foglalkozások szervezésének rendje sem. „Súlyos hibának tekinthető a gyógytestnevelés NAT4-ből, ezáltal az iskolák alaptevékenységéből történő kihagyása." (Hamar, 2016)

Végezetül azon reményünknek adunk hangot, hogy a „gyógyestnevelés” jövője, 
helyének, szerepének, elismertségének kérdésköre, az elméleti kutatók és a gyakorlatban tevékenykedő gyógytestnevelők mellett, az oktatáspolitikai kérdésekkel foglalkozók számára sem lesz érdektelen.

\section{Irodalom}

1. Andrásné Teleki Judit (1998): Könnyitett és gyógytestnevelés. Raabe Kiadó, Budapest.

2. Andrásné Teleki Judit (2013): A gyógytestnevelés, mint testnevelési kategória, „Gyógyító testnevelés" Nemzetközi Szakmai Módszertani Konferencia, Debreceni Egyetem Gyermeknevelési és Felnőttképzési Kar, Hajdúböszörmény, 2013. április 25.
3. Gárdos Magda és Mónus András (1991): Gyógytestnevelés. TF, Budapest. 29-30.

4. Hamar Pál (2016): A testnevelés tantervelmélete. Eötvös József Könyvkiadó, Budapest.

5. Nemessúri Mihály (1965): Gyógytestnevelés. TK, Budapest. 25.

6. AJB 782/2013 sz. jelentése.

7. 11/1994. (VI. 8.) MKM rendelet 1. számú melléklet. 